\title{
A Comparison of Breast-Conserving Surgery and Subcutaneous Mastectomy with Implant Reconstruction in Terms of Postoperative Quality of Life in Patients with Breast Cancer
}

\author{
Abdülkadir Deniz, Kenan Çetin, Hasan Ediz Sıkar, \\ Nuri Emrah Goret, Hasan Küçük
}

Department of General Surgery Kartal Dr. Lütfi Kırdar Training and Research Hospital, İstanbul, Turkey

Submitted: 04.01.2019 Accepted: 02.05.2019

Correspondence: Abdülkadir Deniz, Kartal Dr. Lütfi Kırdar Eğitim ve Araştırma Hastanesi, Genel Cerrahi Kliniği, İstanbul, Turkey E-mail: vakifli@gmail.com

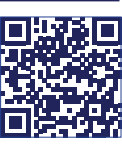

Keywords: Breast; breast conserving surgery; cancer; implant; mastectomy; quality of life; reconstruction; subcutaneous mastectomy.

\section{ब(ब)}

This work is licensed under a Creative Commons Attribution-NonCommercial 4.0 International License.

\begin{abstract}
Objective: The aim of this study was to compare the effects of breast-conserving surgery (BCS) and subcutaneous mastectomy with implant reconstruction (SMIR) in terms of postoperative psychosocial effects, sexuality, and quality of life.

Methods: Demographic data and clinical breast cancer parameters of patients who underwent BCS $(n=48)$ or SMIR $(n=27)$ between January 2012 and December 2016 were reviewed retrospectively. The data were collected via face-to-face interview using the European Organization for Research and Treatment of Cancer Quality of Life Questionnaire (EORTC QLQ-C30) and the breast cancer-specific submodule, EORTC QLQ-BR23.
\end{abstract}

Results: In this study group, 23 (48\%) patients who underwent BCS and 25 (92.6\%) patients who underwent SMIR were premenopausal $(p<0.01)$. More patients in the SIMR group underwent axillary dissection [BCS: I I (22.9\%); SMIR: I7 (63\%)] and had adjuvant therapy [25 $(52 \%)$ vs. $23(85 \%)](p<0.0 I)$. The number of women working outside the home was greater in the SMIR group [BCS: I3 (27\%); SMIR: I8 (66.6\%)] $(\mathrm{p}<0.0 \mathrm{I})$. The EORTCQLQ-C30 and QLQ-BR23 questionnaires revealed no significant difference between the groups in terms of functional scales ( $p>0.05$ ). Fatigue scores on the QLQ-C30 were greater for SMIR patients, as well as arm symptoms in the QLQ-BR23 side effects scale $(p<0.05)$.

Conclusion: The results of BCS patients were better than those of SMIR patients on 3 scales, suggesting that BCS may be the first choice of treatment when feasible. For those who are not eligible, SMIR is an option to consider before a modified radical mastectomy.

\section{INTRODUCTION}

Breast cancer is the second most common cancer among cancers following lung cancer, while it is the most common cancer among women. Deaths from breast cancer are the third among all deaths from cancer. ${ }^{[1]}$ Although its incidence and prognosis vary according to geographical regions, it is reported that the incidence of breast cancer increases by $1.5 \%$ every year and causes significant health problems in women. ${ }^{[2]}$ However, breast cancer is now diagnosed and treated at earlier stages, thanks to advances in diagnostic and screening methods and awareness of patients..$^{[3]}$ Especially in recent years, with the advances in early diagnosis and adjuvant therapies in breast cancer, life expectancy has been prolonged and quality of life has come to the forefront. Surgical procedures applied to patients have changed in parallel and breast-conserving surgery has gained importance..$^{[4]}$

Oncological and aesthetic problems may be encountered in breast-conserving surgery (BCS). Despite advances in surgical technique, $20-30 \%$ positive margins have been reported after BCS in breast cancer ${ }^{[5,6]}$ The rate of aesthetic problems that are difficult to correct in breast is reported as $30 \%$ in conserving surgery. ${ }^{[7]}$ These adversities that lead to low patient satisfaction and poor quality of life, ${ }^{[7,8]}$ highlight the oncoplastic techniques.

Health-related quality of life is defined as the subjective view of one's physical, psychological and social health. Surgery for breast cancer in women can cause various 
concerns and fears. Patients may think that they will lose their femininity and physical integrity with surgery. In a patient experiencing such anxiety may show various reactions such as shock, denial, anger, depression, reflection, psychological regression, despair, harassment, pathological dependence. ${ }^{[9]}$ All of these may not only adversely affect the patient's quality of life, but may also lead to disruptions in the treatment process.

The aim of this study is to investigate the quality of life, social, psychological and sexual life changes after BCS and SMIR, which are the surgical methods in the treatment of breast cancer, by using EORTC QLQ-C30 and EORTC QLQ-BR23 questionnaire forms.

\section{MATERIALS AND METHODS}

\section{Study design and patients}

Patients who underwent breast conserving surgery (Group BCS; $n=48$ ) and subcutaneous mastectomy with implant reconstruction (Group SMIR; $n=27$ ) were included in our study that was conducted between January I, 2012 - December 3I, 2016 in our clinic. Approval was obtained from the ethics committee of our hospital before the study. Data and clinical information of patients were collected by retrospective file scanning method. Patients were reached by phone calls and invited to the clinic, and EORTC QLQ-C30 and EORTC QLQ-BR23 questionnaires were filled by face-to-face interviews.

\section{Analyzed data}

Apart from the quality of life data, other data examined in our study can be listed as follows; demographic information (age, menopausal status, marital status, ability to work), clinical parameters of breast cancer (side, use of neoadjuvant therapy, use of adjuvant chemotherapy) and presence of additional disease.

In our study, the Turkish translation of QLQ-C30 developed by EORTC for cancer patients and QLQ-BR23 questionnaire developed for breast cancer patients were used as quality of life scale. ${ }^{[10]}$ Since the validity and reliability of these questionnaires were shown by Guzelant et al. ${ }^{[1]}$ in the Turkish population previously (in patients with lung cancer), no validity and reliability study was performed in our patient group.

\section{Exclusion criteria}

Patients who didn't want to participate in the study, who could not give appropriate answers to the questionnaire questions due to their intelligence or educational background, who didn't have a time period of at least 6 months after the completion of postoperative treatment (CT-RT), who had metastatic disease and had any previous operations or chronic disease (ASA 3 and above) that would affect the quality of life patients (BCS; $n=57$, SMIR; $n=6$ ) were excluded from the study.

\section{Statistics}

Patient data were analyzed using SPSS 20.0 (IBM) program. Student's $t$ test was used for paired group comparisons of parametric data and Pearson's chi-squared test was used for comparison of data obtained in categorical or ordered scale type in the questionnaire. $P$ values less than 0.05 were considered as statistically significant.

\section{RESULTS}

Seventy-five patients who underwent surgery for breast cancer in our clinic were included in the study. All patients were female and the mean age was $47 \pm 10.6$ (range: 32-65). Forty-eight (64\%) patients underwent breast conserving surgery (Group BCS), and 27 (36\%) underwent subcutaneous mastectomy with implant reconstruction (Group SMIR). The mean age of the patients who underwtent SMIR was 39.9 \pm 7.09 , while the mean age of the patients who underwent BCS was $50.9 \pm 10.23$ $(\mathrm{p}<0.0 \mathrm{I})$. Twenty-three $(48 \%)$ patients in group BCS and $25(92.6 \%)$ patients in group SMIR were premenopausal $(p<0.01)$. Those who underwent axillary dissection during operation [BCS; $n=I \mid(22.9 \%), S M I R ; n=I 7(63 \%)]$ and those who received postoperative adjuvant therapy were higher in the SMIR group [BCS; $n=25$ (52\%), SMIR; $n=23$ $(85 \%)](p<0.01)$. When the work status of the patients were evaluated; work rates were found as higher in SMIR group [13 $(27 \%)$ vs. $18(66.6 \%)](p<0.01)$. Other demographic and clinical characteristics were similar in both groups ( $p>0.05)$.

The comparison of the socioeconomic and clinical characteristics of the patients in both groups is given in Table I.

Postoperative quality of life comparison between groups:

When the EORTC QLQ C30 questionnaire was examined according to the groups, no statistically significant difference was found between the mean values in the functional scales $(p>0.05)$. When the symptom scales were exam-

Table I. Demographic findings and clinical characteristics of patients

\begin{tabular}{|c|c|c|c|}
\hline & $\begin{array}{c}\text { BCS } \\
(n=48)\end{array}$ & $\begin{array}{c}\text { SMIR } \\
(n=27)\end{array}$ & $\mathbf{p}$ \\
\hline Age $($ mean $\pm S D)$ & $50.9 \pm 10.23$ & $39.9 \pm 7.09$ & $<0.001$ \\
\hline Menopausal, n (\%) & $25(52)$ & $2(7.4)$ & $<0.001$ \\
\hline Side (right), n (\%) & $27(56.3)$ & $15(55.6)$ & 0.95 \\
\hline With neoadjuvant, n (\%) & $3(6.2)$ & $5(18.5)$ & 0.13 \\
\hline Additional disease (+), n (\%) & $15(3 \mid .2)$ & $4(14.8)$ & 0.12 \\
\hline Adjuvant receivers, $n(\%)$ & $25(52)$ & $23(85)$ & $<0.001$ \\
\hline RT receivers, n (\%) & $33(68.7)$ & $18(66.6)$ & 0.85 \\
\hline Married, n (\%) & $39(81.2)$ & 21 (77.7) & 0.72 \\
\hline Working, n (\%) & $13(27)$ & $18(66.6)$ & $<0.001$ \\
\hline Axillary curettage (+), n (\%) & II (22.9) & $17(63)$ & $<0.001$ \\
\hline
\end{tabular}

BCS: Breast-conserving surgery; SMIR: Subcutaneous mastectomy with implant reconstruction; RT: Radiotherapy; SD: Standard deviation. 
Table 2. EORTC QLQ C $30 \mathrm{BCS}$ and OBS questionnaiere results

\begin{tabular}{|c|c|c|c|}
\hline \multirow[t]{2}{*}{ Scale } & \multirow{2}{*}{$\frac{\text { BCS }}{\text { Mean } \pm \text { SD }}$} & \multirow{2}{*}{$\frac{\text { SMIR }}{\text { Mean } \pm \text { SD }}$} & \multirow[t]{2}{*}{$\mathbf{p}$} \\
\hline & & & \\
\hline \multicolumn{4}{|l|}{ Functional scales } \\
\hline Physical function & $81.8 \pm 19.0$ & $81.5 \pm 14.2$ & 0.9 \\
\hline Role functioning & $85.1 \pm 18.6$ & $86.4 I \pm 24$ & 0.8 \\
\hline Cognitive status & $82.9 \pm 22.7$ & $77.8 \pm 22.2$ & 0.3 \\
\hline Psychological status & $66.8 \pm 22.4$ & $70.1 \pm 25.7$ & 0.6 \\
\hline Social status & $71.9 \pm 24.6$ & $70.4 \pm 25.7$ & 0.8 \\
\hline General well-being & $64.8 \pm 24.1$ & $67.6 \pm 33.8$ & 0.6 \\
\hline \multicolumn{4}{|l|}{ Symptom scales } \\
\hline Dyspnea & $19.4 \pm 25.6$ & $17.3 \pm 28.3$ & 0.7 \\
\hline Nausea and vomiting & $13.5 \pm 21.9$ & $16.0 \pm 24.2$ & 0.6 \\
\hline Anorexia & $23.6 \pm 32.2$ & $22.2 \pm 32$ & 0.9 \\
\hline Sleep disorder & $38.9 \pm 37.9$ & $30.86 \pm 33.2$ & 0.4 \\
\hline Pain & $25.3 \pm 24.1$ & $33.9 \pm 24.7$ & 0.1 \\
\hline Fatigue & $25 \pm 22.3$ & $38.7 \pm 22.9$ & 0.014 \\
\hline Constipation & $19.4 \pm 29$ & $|9.8 \pm 3|$ & 0.9 \\
\hline Diarrhea & $11.8 \pm 22.8$ & $6.2 \pm 16.1$ & 0.3 \\
\hline Financial challenge & $27.1 \pm 31.3$ & $40.7 \pm 44.7$ & 0.1 \\
\hline
\end{tabular}

OBS: Oncoplastic Breast Surgery; BCS: Breast-conserving surgery; SMIR: Subcutaneous mastectomy with implant reconstruction; SD: Standard deviation.

Table 3. EORTC QLQ BR23 BCS and OBS questionaire results

\begin{tabular}{lcccc}
\hline Scale & BCS & & SMIR & p \\
\cline { 5 - 5 } & Mean \pm SD & & Mean \pm SD & \\
\hline Functional scales & & & \\
$\quad$ Body image & $64.6 \pm 18.2$ & & $56.2 \pm 29.3$ & 0.1 \\
$\quad$ Sexual life & $41.1 \pm 32.7$ & & $35.6 \pm 28.9$ & 0.1 \\
$\quad$ Sexual satisfaction & $43.8 \pm 28.6$ & & $40.2 \pm 29.4$ & 0.6 \\
$\quad$ Future expectation & $50 \pm 29.9$ & & $50.61 \pm 37.4$ & 0.9 \\
Symptom scales & & & & \\
$\quad$ Side effects & $22.6 \pm 16.2$ & & $37.5 \pm 15.8$ & $<0.001$ \\
$\quad$ Breast symptoms & $20.1 \pm 17.9$ & & $27.8 \pm 19.1$ & 0.09 \\
$\quad$ Arm symptoms & $22.7 \pm 23.1$ & & $42.8 \pm 26.8$ & 0.001 \\
$\quad$ Hair loss & $40.7 \pm 35.3$ & & $43.5 \pm 40.7$ & 0.8 \\
\hline
\end{tabular}

OBS: Oncoplastic Breast Surgery; BCS: Breast-conserving surgery; SMIR: Subcutaneous mastectomy with implant reconstruction; SD: Standard deviation.

ined, it was seen that the fatigue score of the SMIR group was higher $(p<0.05)$. No significant difference was found for the remaining symptom scales ( $p>0.05$ ) (Table 2 ).

When EORTC QLQ BR 23 questionnaire was examined, no significant difference was found between the functional scale scores between the groups ( $p>0.05$ ) (Table 3).

When the symptom scales were examined; side effects and arm symptoms scores were significantly higher in SMIR group $(p<0.05)$. No significant difference was found in the other two symptom scales ( $p>0.05)$ (Table 3$)$.

\section{DISCUSSION}

Radical mastectomy (RM), defined by Halsted since the 1890s, has been used as a standard for the treatment of breast cancer for the last century. ${ }^{[12]}$ Although RM, which has a significant high morbidity, has been successful with local control in most patients, a significant number of patients have been lost with distant metastases after a certain period of time. With this reality, more limited modified radical mastectomies (MRM), with added systemic treatments and BCS with postoperative radiotherapy were introduced and successfully applied since the 1970s. In addition, in the light of the research conducted by the National Surgical Adjuvant Breast and Intestine Project Protocol B-06 (NSABP B-06) and the Milan Cancer Institute, the American National Cancer Institute $(\mathrm{NCl})$, the European Cancer Research and Treatment Organization (EORTC), the Danish Breast Cancer Group and Gustave Roussy Institute, which have achieved similar results, in the 1990 consensus meeting of the American National Institute of Health $(\mathrm{NIH})$, it was concluded that BCS and radiotherapy are appropriate primary treatment modalities in early-stage breast cancers, as they have the advantage of preserving the breast, which has similar rates to the overall survival rates provided by MRM."[ ${ }^{[13]}$

The most important question today is the extent to which breast conserving surgery can preserve the quality of life of the patients, which maintains the appearance of the breast to a large extent, but places a burden of radiotherapy on all patients. There are very few clinical studies investigating the effects of surgical procedures in patients with breast cancer on quality of life, social, psychological and sexual life of the patients, and the effects of surgical procedures are generally emphasized depending on their types. ${ }^{[10]}$

EORTC QLQ surveys are widely used in clinical trials in Western populations. In our study, the EORTC QLQ- C30 and EORTC BR-23 were preferred because of the presence of the Turkish version of the questionnaires, they were easily understandable, internationally recognized and their validity and reliability have been shown also in Turkey, and the questions they contain were appropriate for our study.

When we look at the literature, we found that the number of patients differed from at least 120 and at most 407 patients in 3 different studies that were similar to our study. [14-16] Nissen et al. ${ }^{[14]}$ compared the postoperative quality of life in patients who underwent BCS $(n=103)$, mastectomy $(n=55)$, and mastectomy + reconstruction $(n=40)$. In this study, mental status score was higher and general well-being score was lower in mastectomy + reconstruction group, compared to mastectomy group. Similarly, in the BCS group, mental status scores were higher than with mastectomy, but there was no significant difference in terms of general well-being with the mastectomy group's scores. These differences from BCS and mastectomy + reconstruction compared to mastectomy alone could not be detected between BCS and mastectomy + reconstruction. In our study, no significant difference was found between 
BCS and SMIR groups in terms of general well-being and mental function scales.

Sun et al. ${ }^{[15]}$ compared postoperative quality of life of 407 patients who underwent BCS $(n=254)$, mastectomy $(n=122)$, and mastectomy + reconstruction $(n=31)$. According to the study results, they found physical and mental function, nausea and vomiting, body image, anxiety, financial difficulty and arm symptoms scores of patients in BCS group superior to mastectomy and mastectomy + reconstruction group. They reported higher scores on sexual life and sexual satisfaction scales in the mastectomy + reconstruction group. In our study, we found the scores in physical function, mental function, body image, sexual life and sexual satisfaction scales to be similar among our groups.

Kaviani et al. ${ }^{[16]}$ compared patients who underwent BCS $(n=57)$ and Oncoplastic Breast Surgery (OBS) (Reduction or remodeling mammoplasty) $(n=63)$. In this study, no significant difference was found between functional and symptom scales between the two groups according to EORTC QLQ C30 questionnaire. In the BR23 survey specific to breast cancer, better results were found only in arm symptoms in favor of OBS. In our study, according to the QLQ C30 questionnaire, significant results were obtained in favor of BCS only in fatigue symptoms. In the BR23 questionnaire, side effects and arm symptoms scales were found to be significant in favor of BCS.

In our study, it was seen that the rate of receiving adjuvant therapy in our patients in the SMIR group was higher. This led to a significant difference in both side effects and fatigue symptoms between the two groups. The reason for the higher arm symptoms in SMIR is that the rate of axillary dissection is higher in the SMIR group. Other limitations of our study were as follows: it was a retrospective study, it has a low patient volume, demographic findings and clinical parameters were not similar in both groups and the non-participation of mastectomy patients.

\section{CONCLUSION}

When we evaluated the quality of life of patients undergoing BCS and SMIR, BCS was found to be superior to SMIR on three scales (fatigue, side effects and arm symptoms) symptomatically. On the other hand, it is stated in the literature that BCS patients have better postoperative quality of life compared to MRM. According to these results, BCS is the first choice procedure for surgical treatment of breast cancer patients. In patients who are not compatible with BCS, SMIR option with similar functional quality of life with BCS should be recommended instead of conventional mastectomy. The data of our study should be supported by prospective studies with higher volume and with separate evaluations using pre-operative and postoperative quality of life questionnaires.

Ethics Committee Approval

Approved by the local ethics committee.
Informed Consent

Retrospective study.

Peer-review

Internally peer-reviewed.

Authorship Contributions

Concept: A.D.; Design: K.Ç., A.D.; Supervision: H.E.S.; Data: N.E.G., A.D.; Analysis: K.Ç.; Literature search: A.D., K.Ç.; Writing: A.D., K.Ç.; Critical revision: H.K.

Conflict of Interest

None declared.

\section{REFERENCES}

1. Burstein HJ, Harris JR, Morrow M. Malignant tumors of the breast. In: De Vita VT Jr, LAwrence TS, Rosenberg SA, editors. DeVita, Hellman and Rosenberg's Cancer; Principles \& Practice of Oncology. Lippincott Williams \& Wilkins; 2011. p. 1401-46.

2. Yllmaz MR. Meme Kanserinin Epidemiyolojisi ve Etiyolojisi. Meme Kanseri. In: Esin Emin Üstün editor. İzmir: Ege Üniversitesi Tip Fakültesi Dekanlığı, Yayın Bürosu; 2002. p. 25-40.

3. Brenin DR, Morrow M, Moughan J, Owen JB, Wilson JF, Winchester DP. Management of axillary lymph nodes in breast cancer: a national patterns of care study of 17,151 patients. Ann Surg 1999;230:68691.[CrossRef]

4. Veiga DF, Veiga-Filho J, Ribeiro LM, Archangelo I Jr, Balbino PF, Caetano LV, et al. Quality-of-life and self esteem outcomes after oncoplastic breast-conserving surgery. Plast Reconstr Surg 2010;125:811-7. [CrossRef]

5. Singletary SE. Surgical margins in patients with early-stage breast cancer treated with breast conservation therapy. Am J Surg 2002;184:383-93. [CrossRef]

6. Yang JD, Lee JW, Cho YK, Kim WW, Hwang SO, Jung JH, et al. Surgical techniques for personalized oncoplastic surgery in breast cancer patients with small- to moderate-sized breasts (part 2): volume replacement. J Breast Cancer 2012;15:7-14. [CrossRef]

7. Clarke M, Collins R, Darby S, Davies C, Elphinstone P, Evans V, et al. Effects of radiotherapy and of differences in the extent of surgery for early breast cancer on local recurrence and 15-year survival: an overview of the randomised trials. Lancet 2005;366:2087-106. [CrossRef]

8. Sneeuw KC, Aaronson NK, Yarnold JR, Broderick M, Regan J, Ross $\mathrm{G}$, et al. Cosmetic and functional outcomes of breast conserving treatment for early stage breast cancer. 2. Relationship with psychosocial functioning. Radiother Oncol 1992;25:160-6. [CrossRef]

9. Özkan S, Meme Kanserli Hastaya Psikolojik Yaklaşım. VIII. Ulusal Meme Hastalıkları Kongresi Özet Kitabı, 2005, s. 21-4.

10. Zanapalıŏlu, Y, Atahan K, Gür S,Çökmez A, Tarcan E, et al. , Effect Of Breast Conserving Surgery In Quality Of Life In Breast Cancer Patients. The Journal Of Breast Health 2009;5:152-6.

11. Guzelant A, Goksel T, Ozkok S, Tasbakan S, Aysan T, Bottomley A. The European Organization for Research and Treatment of Cancer QLQ-C30: an examination into the cultural validity and reliability of the Turkish version of the EORTC QLQ-C30. Eur J Cancer Care (Engl) 2004;13:135-44. [CrossRef]

12. Rabinovitch R, Kavanagh B. Double Helix of breast cancer therapy: intertwining the Halsted and Fisher hypotheses. J Clin Oncol 2009;27:2422-3. [CrossRef]

13. Fisher B, Bauer M, Margolese R, Poisson R, Pilch Y, Redmond C, et al. Five-year results of a randomized clinical trial comparing total mastectomy and segmental mastectomy with or without radiation in the treatment of breast cancer. N Engl J Med 1985;312:665-73. [CrossRef] 
14. Nissen MJ, Swenson KK, Ritz LJ, Farrell JB, Sladek ML, Lally RM. Quality of life after breast carcinoma surgery: a comparison of three surgical procedures. Cancer 2001;91:1238-46. [CrossRef]

15. Sun Y, Kim SW, Heo CY, Kim D, Hwang Y, Yom CK, et al. Comparison of quality of life based on surgical technique in patients with breast cancer. Jpn J Clin Oncol 2014;44:22-7. [CrossRef]

16. Kaviani A, Mir M, Daryani A, Bonyadi M, Ebrahimi M, Neishaboury M, et al. Quality Of Life After Breast Concervation Versus Onoplastic Surgery. Archives Of Breast Concervation Versus Oncoplastic Surgery 2015;2:46-51.

\section{Meme Kanserli Hastalarda Meme Koruyucu Cerrahi'nin Subkutan Mastektomi- Implant ile Rekonstriksyon Uygulananlarla Ameliyat Sonrası Yaşam Kalitesi Açısından Karşılaştııııması}

Amaç: Meme koruyucu cerrahi (MKC) ile subkutan mastektomi-implant ile rekonstrüksiyon (SMIR) uygulanan hastaların ameliyat sonrası psikososyal, cinsel ve genel yaşam kaliteleri üzerindeki etkilerinin karşılaştırılması amaçlandı.

Gereç ve Yöntem: Ocak 2012 ile Aralık 2016 tarihleri arasında meme kanseri tanısı ile MKC ( $n=48)$ ve SMiR ( $n=27)$ uygulanan hastaların demografik verileri ve meme kanseri klinik parametreleri geriye dönük olarak incelendi. Yaşam kalitesi verileri, yüz yüze görüşme ile EORTC QLQ-C30 (European Organisation for the Research and Treatment of Cancer Quality of Life) ve meme kanserine özel alt modülü EORTC QLQ-BR23 anketleri uygulanarak elde edildi.

Bulgular: Grup MKC'deki hastaların 23'ü (\%48), Grup SMiR'dekilerin 25’i (\%92.6) premenopozaldi ( $\mathrm{p}<0.0 \mathrm{I})$. Aksiller küraj uygulananlar [MKC; II (\%22.9), SMiR; 17 (\%63)] ve adjuvan tedavi alanlar SMiR grubunda daha fazlaydı [MKC; 25 (\%52), SMiR; 23 (\%85)] ( $<<0.01)$. SMiR grubunda çalsşma oranları daha yüksekti [I3'e (\%27) karşı I8 (\%66.6)] ( $<<0.01)$. Diğer demografik ve klinik özellikler her iki grupta benzerdi ( $p>0.05$ ). EORTC QLQ-C30 ve EORTC QLQ-BR23 anketlerinde gruplar arasında fonksiyonel ölçekler açısından fark saptanmadı ( $>>0.05)$. Semptom ölçeklerinde EORTC QLQ-C30'da yorgunluk için, EORTC QLQ-BR23 ölçeğinde yan etkiler ve kol semptomlarında SMiR grubunun skorları yüksekti $(p<0.05)$.

Sonuç: Hastaların ameliyat sonrası yaşam kaliteleri değerlendirildiğinde; MKC semptomatik olarak üç ölçekte SMiR'e göre daha üstündür ve cerrahi tedavide ilk seçenektir. MKC uygulanamayan olgularda; SMiR, mastektominin yerine önerilmelidir.

Anahtar Sözcükler: İmplant; kanser; mastektomi; meme; meme kouruyucu cerrahi; rekonstrüksiyon; subkutan mastektomi; yaşam kalitesi. 